\title{
The Chemical Composition and Productivity of Vaccinium myrtillus L. under Influence of Industrial Pollution
}

\author{
Larisa V. Afanasyeva* and Vladimir K. Kashin \\ Institute of General and Experimental Biology SB RAS \\ 6 Sakhyanovoy Str., Ulan-Ude, 670047, Russia
}

Received 25.09.2014, received in revised form 10.03.2015, accepted 12.05.2015

The content and distribution of chemical elements ( $\mathrm{S}, \mathrm{Mn}, \mathrm{Fe}, \mathrm{Zn}, \mathrm{Cu}, \mathrm{Co}, \mathrm{Cr}, \mathrm{Ni}, \mathrm{Pb}$ and $\mathrm{Cd}$ ) and phenolic compounds were determined in the above-ground and underground parts of bilberry (Vaccinium myrtillus L.), grown on the background and technogenic polluted territories of the Southern Baikal region. Plants and soil were sampled at polluted site situated 0.5-1.0 km from Baikal Pulp and Paper Mill (East Siberia) and at a relatively clean site. It was shown that in background conditions $\mathrm{Fe}, \mathrm{Ni}, \mathrm{Cr}, \mathrm{Pb}$ and $\mathrm{Cd}$ accumulated in roots of $\mathrm{V}$. myrtillus, $\mathrm{Mn}$ and $\mathrm{Zn}$ accumulated in stems, $S$ and $C o$ in leaves and $C u$ in berries. It should be noted, that the absorption intensity of the elements of the $V$. myrtillus reproductive organs is lower than of the vegetative one. The content of phenolic compounds in bilberries plants decreases in the following order: leaves $>$ stems $>$ berries $>$ roots, and the content of flavonoids in the order leaves $>$ berries $>$ stems $>$ roots. Amount of berries on a shrub varies from 0 to 17 units in the background conditions. The berries productivity was from 11 to $34 \mathrm{~g} / \mathrm{m}^{2}$. It was shown, that the berries productivity depends on the number and weight of the berries on the shrub $(r=0.55-0.68, p<0.05)$.

In the site influenced by the industrial emissions of Baikal Pulp and Paper Mill bilberry above-ground parts contained significantly higher concentration of $S$ and significantly lower concentrations of $\mathrm{Mn}$ and $\mathrm{Zn}$. Coefficients of biophilic elements accumulation decreased 1.42.0 times, that indicates a violation of their absorption by plant roots. Furthermore, leaves had significantly higher level of total phenolics and flavonoids as compared with bilberry leaves from non-polluted site. Plants of the polluted site had a lower height and amount of berries. The berries productivity was significantly lower $(1.1 \pm 0.3 \mathrm{~g}$ per shrub in the polluted site compared with $2.0 \pm 0.5 \mathrm{~g}$ per shrub in the background one). At the same time the weight of one berry did not differ between the two sites. Reduction of the shrub morphometric parameters leads to a decrease in their aboveground biomass of an average of 1.5 times, berries productivity $\left(\mathrm{g} / \mathrm{m}^{2}\right)$ decreased 1.7 times.

(c) Siberian Federal University. All rights reserved

* Corresponding author E-mail address: afanl@mail.ru 
Keywords: Vaccinium myrtillus, chemical elements, phenolic compounds, productivity, industrial pollution, Southern Baikal.

DOI: $10.17516 / 1997-1389-2015-8-3-333-346$.

\title{
Химический состав и продуктивность Vaccinium myrtillus L. \\ в условиях техногенного воздействия
}

\author{
Л.В. Афанасьева, В.К. Кашин \\ Институт общей и экспериментальной биологии СО РАН \\ Россия, 670047, Улан-Удэ, ул. Сахьяновой, 6
}

Определены уровни накопления и особенности распределения химических элементов ( $\mathrm{S}, \mathrm{Mn}, \mathrm{Fe}$, $\mathrm{Zn}, \mathrm{Cu}, \mathrm{Co}, \mathrm{Cr}, \mathrm{Ni}, \mathrm{Pb}, \mathrm{Cd})$, а также фенольных соединений в растениях черники обыкновенной (Vaccinium myrtillus L.) на фоновых и загрязненных аэропромвыбросами ОАО «Байкальский иеллюлозно-бумажный комбинат» территориях Южного Прибайкалья. Анализ распределения элементов по органам черники показал, что в фоновых условиях корни черники отличаются наиболее высоким содержанием $\mathrm{Fe}, \mathrm{Ni}, \mathrm{Cr}, \mathrm{Pb}, \mathrm{Cd}$, стебли-Mn, Zn, листья-S и Co, ягоды - Cu. Общее содержание фенольных соединений в растениях черники снижается в ряду листья > стебли > ягоды > корни, флавоноидов-листья > ягоды > стебли > корни. В фоновых условиях количество ягод на одном парииальном кусте варьирует от 0 до 17 ит., урожайность ягод - от

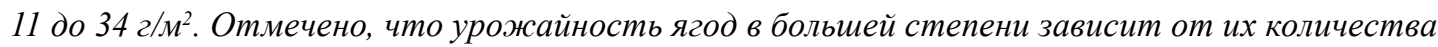
и массы на одном парииальном кусте $(r=0.55-0.68, p<0.05)$ и в меньшей - от количества плодоносящих кустов ( $r=0.34-0.45, p<0.05)$. Высота куста, параметры кроны существенного влияния на величину урожайности ягод не оказывают.

В зоне атмосферных промымленных выбросов ОАО «БЦБК» в надземных частях черники при увеличении содержания $S$ в 1.7-1.8 раза наблюдалось снижение концентрации $\mathrm{Mn}$ и Zn в 1.5-2.3 раза и повымение уровня флавоноидов в 1.3-1.5 раза. Коэффициенты накопления большинства рассмотренных элементов снижались, причем для биофильных элементов в 1.42.0 раза. Обнаружено уменьшение средней высоты парциальных кустов и протяженности кроны в 1.4 раза, количества ягод и их массы на парииальном кусте в 1.5-1.8 раза по сравнению с фоновыми значениями, тогда как диаметр кроны и масса одной ягоды практически не изменялись. Снижение морфометрических параметров парииальных кустов приводит к уменьшению их надземной фитомассы в среднем в 1.5 раза, а урожайности - в 1.7 раза.

Ключевые слова: Vaccinium myrtillus, химические элементы, фенольные соединения, продуктивность, техногенное загрязнение, Южное Прибайкалье. 


\section{Введение}

Одной из актуальных проблем современности является ухудшение качества окружающей среды в условиях усиливающегося антропогенного пресса. В промышленно развитых регионах атмосферные эмиссии становятся наиболее значимым негативным фактором, приводящим к нарушениям в структурной организации отдельных популяций растений и биогеоценозов в целом, вплоть до их полной деградации (Безель и др., 2001; Проблемы..., 2005; Мазная, Лянгузова, 2010).

Территория Южного Прибайкалья на протяжении 46 лет подвергалась воздействию атмосферных промышленных выбросов локального источника загрязнения - Байкальского целлюлозно-бумажного комбината (ОАО «БЦБК»). Максимум загрязнения окружающей среды пришелся на конец 1970-х начало 1980-х гг., когда объем атмосферных выбросов комбината составлял более 30 тыс. т в год. Промышленные эмиссии БЦБК включали сернистый ангидрид, сероводород, соединения метилмеркаптанового ряда, терпеновые углеводороды, оксиды азота, углерода, хлора, фенолы, метанол, аэрозоли тяжелых металлов. В результате последующих технологических мероприятий, проводимых на БЦБК, и снижения производства общий объем эмиссий значительно сократился и в 20102011 гг. составлял 2.9-5.3 тыс. т в год, в том числе диоксида серы - 1.2-3.2 тыс. т в год (Госдоклад..., 2012). 25 декабря 2013 г. комбинат официально прекратил свою деятельность (http://ru.wikipedia.org).

Одним из доминантных видов травянокустарничкового яруса темнохвойных лесов Южного Прибайкалья, играющих значимую роль в накоплении органического вещества, а следовательно, и в биологическом круговороте веществ лесных экосистем, является черника обыкновенная (Vaccinium myrtillus L.).
Ягоды черники служат традиционным источником питания для местного населения, а также кормом для птиц и животных. Кроме того, облиственные побеги обладают противовоспалительной, общеукрепляющей, гипогликемической активностью; биологически активные вещества, полученные из плодов, входят в состав лекарственных препаратов (Дикорастущие..., 2001).

Несмотря на продолжительный период работы комбината, исследований состояния популяций $V$. myrtillus, особенностей ее химического состава в этом районе не проводилось, хотя такие данные имеют не только теоретическое, но и практическое значение. Так, эколого-популяционный мониторинг позволяет выявить закономерности поведения ягодных кустарничков в стрессовых условиях, понять механизмы адаптации растений, испытывающих техногенное воздействие, а на основе химического состава можно оценить качество и безопасность ягод и листьев растений и возможность их сбора населением. Кроме того, элементный состав ассимиляционных органов растений служит основой химического мониторинга состояния как отдельных компонентов, так и всей экосистемы в целом (Лукина, Никонов, 1996).

Наряду с традиционным изучением элементного химического состава растений особый интерес представляет определение содержания фенольных соединений, обладающих высокой реакционной способностью и биологической активностью. Черника, как и многие представители семейства вересковых (Ericaceae), накапливает значительные концентрации фенольных соединений (Запрометов, 1993), что рассматривается как один из механизмов их устойчивости в условиях воздействия неблагоприятных факторов, в том числе техногенных эмиссий (Michalak, 2006; Mroz, Demczuk, 2010). В этой связи изменение 
содержания фенольных соединений может быть использовано в качестве биомаркера загрязнения (Bialońska et al., 2007; Артемкина, 2010).

Целью настоящей работы было изучение химического состава $V$. myrtillus (содержание химических элементов, фенольных соединений) и продуктивности ее ценопопуляций на фоновых и техногенно-загрязненных территориях Южного Прибайкалья.

\section{Материалы и методы}

Исследования были выполнены в 2010 г. на территории Южного Прибайкалья (северный макросклон хр. Хамар-Дабан), для которой характерны горный резко расчлененный рельеф, умеренно континентальный, влажный климат (годовое количество осадков 900-1100 мм, средняя температура января минус $16,5{ }^{\circ} \mathrm{C}$, июля $-12,1{ }^{\circ} \mathrm{C}$ ) (Байкал, 1993). Почвенный покров сформирован на хрящевато-щебнистом элювии гранитов грубого песчанистого состава. Преобладают горно-таежные почвы, представленные преимущественно подбурами, подзолами и буроземами. Лесной пояс занимает высоты от 460 до 1800 м над ур. м. В верхней части склона доминируют кедрово-пихтовые леса зеленомошной группы типов леса, в средней и нижней частях - пихтовые, пихтовокедровые, березовые, березово-сосновые леса крупнотравной, папоротниковой и чернично-зеленомошной групп типов леса (Типы..., 1980).

Объектом исследований служили растения черники обыкновенной ( $V$. myrtillus), произрастающие в березняках черничнозеленомошных на перегнойных оподзоленных подбурах. Пробные площади (ПП) были заложены в лесных массивах, удаленных на 40-50 км (фоновый район) и 0.5-1.0 км (импактная зона) к востоку от ОАО «БЦБК» (в направлении преобладающего атмосферного переноса) (Методы..., 2002). ПП, размером по 0.2 га каждая, были сопоставимы по положению в рельефе, таксационным показателям древостоя, видовому составу напочвенного покрова. Древесный ярус исследуемых лесов образован березой повислой (Betula pendula Roth.) с примесью сосны обыкновенной (Pinus sylvestris L.), ели сибирской (Picea obovata Ledeb.) и пихты сибирской (Abies sibirica Ledeb.). В сложении травяно-кустарничкого яруса доминирует $V$. myrtillus, общее проективное покрытие которой составляет в среднем $60-70 \%$. В составе мохово-лишайникового яруса доминирует Pleurozium schreberi (Brid.) Mitt., виды родов Dicranum и Cladonia.

V. myrtillus относится к вегетативно подвижным кустарничкам, формирующим систему парциальных кустов, связанных между собой подземными побегами (корневищами) (Мазная, Лянгузова, 2010), поэтому за счетную единицу был принят отдельный парциальный куст. Для определения морфометрических параметров, запасов надземной фитомассы и урожайности растений $V$. myrtillus на каждой ПП в период полного созревания ягод (конец июля - начало августа) было заложено по 10 площадок размером $0.5 \mathrm{x} 0.5 \mathrm{~m}$, размещенных случайным способом. На площадках определяли общую высоту парциальных кустов, диаметр, протяженность кроны, количество и массу ягод, массу побегов.

Для определения элементного химического состава на каждой ПП методом квадрата отбирали пять точечных образцов, состоящих из 3-5 растений средневозрастного генеративного состояния. Растения разделяли на отдельные органы: корни (анализировали придаточные корни подземных побегов), стебли, листья, ягоды. Корни тщательно очищали от видимых примесей, промывали вначале в проточной, затем в дистиллированной воде. 
Одновременно отбирали почвенные образцы в перегнойно-аккумулятивном горизонте на глубине 0-20 см.

В лабораторных условиях определение влажности образцов проводили в 3-кратной повторности после их высушивания в сушильном шкафу до постоянного веса при температуре $105{ }^{\circ} \mathrm{C}$. Основную часть растительных и почвенных образцов высушивали до воздушно-сухого состояния, после чего измельчали и просеивали. Для измельчения почвенных образцов использовали фарфоровые ступки, растительные пробы перемалывали до порошкообразного состояния на электромельнице. Почвенные образцы просеивали через сита с диаметром отверстий 1.0 мм, растительные -0.5 мм. Перед выполнением аналитических работ в пробах определялась гигроскопическая влажность, для растений температура высушивания составляла $60{ }^{\circ} \mathrm{C}$, для почв $-105^{\circ} \mathrm{C}$.

Концентрации микроэлементов ( $\mathrm{Mn}, \mathrm{Fe}$, $\mathrm{Zn}, \mathrm{Cu}, \mathrm{Co}, \mathrm{Cr}, \mathrm{Ni}, \mathrm{Pb}, \mathrm{Cd}$ ) определяли атомноабсорбционным методом на спектрофотометре «AAnalyst 400» (Perkin Elmer, США). В растительных образцах - после предварительного сухого озоления проб в муфельной печи при температуре $450{ }^{\circ} \mathrm{C}$ (Методы..., 1987). Из почвы подвижные формы металлов извлекали раствором $1 \mathrm{H} \mathrm{HNO}_{3}$ при соотношении почвы к кислоте 1:10, время экстракции 1 ч (Теория..., 2006).

Содержание серы, основного элемента, входящего в состав эмиссий, определяли спектрофотометрическим методом: в растительных образцах после озоления материала в муфельной печи при температуре $520{ }^{\circ} \mathrm{C}$ (Мочалова, 1975), из почвы подвижные формы элемента извлекали $1 \mathrm{H} \mathrm{KCl} \mathrm{(Теория...,} \mathrm{2006).}$ Определение кислотности почвенного раство$\mathrm{pa}\left(\mathrm{pH}_{\text {КС }}\right)$ производили потенциометрически. Для оценки интенсивности накопления хи- мических элементов растениями $V$. myrtillus из почвы были рассчитаны коэффициенты накопления $\left(K_{t}\right)$ - отношение содержания элемента в органах растений к содержанию его подвижных форм в почве (Ильин, 1995). По величине $K_{н}$ выделяют следующие группы: 1) энергичного накопления (100> $\left.K_{н} \geq 10\right)$; 2) сильного накопления (10> $\left.K_{u} \geq 1\right)$; 3$)$ слабого накопления (1> $\left.K_{н} \geq 0.1\right)$; 4 с слабого захвата $\left(0.1>K_{н} \geq 0.01\right)$.

Общее содержание фенолов в растениях определяли с реактивом Фолина-Чокалтеу, используя галловую кислоту в качестве стандарта (Mroz, Demczuk, 2010); флавоноиды - по реакции с хлоридом алюминия в пересчете на рутин (Методы..., 1987). Все анализы выполнялись в 3-кратной повторности, расчет произведен на абсолютно сухую массу.

Статистическую обработку результатов проводили с использованием стандартных методов (Зайцев, 1990) и пакета программ Statistica 8.0. Для оценки достоверности различий средних значений исследуемых показателей использовали непараметрический критерий Манна-Уитни.

\section{Результаты и обсуждение}

\section{Элементный химический}

coстав растений V. myrtillus

В связи с разной физиологической значимостью химических элементов и избирательностью поглощения из почв их содержание в растениях существенно различается. Средние концентрации изучаемых нами элементов изменялись в растениях черники от $0.2(\mathrm{Cd})$ до 1234 (Mn) мг/кг (табл. 1). Анализ распределения элементов по органам черники показал, что в фоновых условиях корни черники отличаются наиболее высоким содержанием $\mathrm{Fe}$, $\mathrm{Ni}, \mathrm{Cr}, \mathrm{Pb}, \mathrm{Cd}$, стебли - Mn, Zn, листья - S и $\mathrm{Co}$, ягоды - Cu. В целом ягоды содержат наименьшее количество элементов, что, с одной 
Таблица 1. Содержание химических элементов $(M \pm m)$ в растениях Vaccinium myrtillus и в почве на фоновой (над чертой) и техногенно-загрязненной (под чертой) территориях Южного Прибайкалья, мг/кг сухого вещества, $\mathrm{n}=5$ для каждой территории

\begin{tabular}{|c|c|c|c|c|c|c|}
\hline \multirow[b]{2}{*}{ Элемент } & \multicolumn{4}{|c|}{ Часть растения } & \multirow[b]{2}{*}{ Почва } & \multirow{2}{*}{$\begin{array}{l}\text { ПДК подвижных форм } \\
\text { элементов в почве } \\
\text { (Чулджиян и др., 1988) }\end{array}$} \\
\hline & Ягоды & Листья & Стебли & $\begin{array}{c}\text { Подземные } \\
\text { органы }\end{array}$ & & \\
\hline \multirow{2}{*}{$\mathrm{S}$} & $469.8 \pm 42.2$ & $\underline{540.4 \pm 58.2}$ & $228.4 \pm 24.2$ & $\underline{179.8 \pm 16.2}$ & $5.8 \pm 0.4$ & \multirow{2}{*}{-} \\
\hline & $\overline{549.6 \pm 62.8}$ & $\overline{1019.7 \pm 98.1}$ & $397.2 \pm 36.4$ & $228.4 \pm 38.4$ & $7.6 \pm 0.1$ & \\
\hline \multirow{2}{*}{$\mathrm{Fe}$} & $\underline{24.5 \pm 2.8}$ & $\underline{91.3 \pm 9.1}$ & $\underline{92.2 \pm 8.6}$ & $\underline{106.3 \pm 9.2}$ & $\underline{226} . \underline{2 \pm 18.4}$ & \multirow{2}{*}{-} \\
\hline & $32.5 \pm 4.6$ & $97.6 \pm 8.1$ & $92.6 \pm 5.4$ & $108.2 \pm 9.6$ & $398.4 \pm 11.6$ & \\
\hline \multirow{2}{*}{$\mathrm{Mn}$} & $\underline{357.8 \pm 11.6}$ & $\underline{1233.7 \pm 65.4}$ & $\underline{1378.1 \pm 68.2}$ & $\underline{325.8} \pm 18.2$ & $\underline{178 \pm 10}$ & \multirow{2}{*}{600.0} \\
\hline & $\overline{168.7 \pm 8.5}$ & $\overline{543.1 \pm 35.7}$ & $\overline{704.4 \pm 48.2}$ & $\overline{252.2 \pm 24.4}$ & $\overline{151 \pm 13}$ & \\
\hline \multirow{2}{*}{$\mathrm{Zn}$} & $\underline{16.8 \pm 0.8}$ & $\underline{19.2 \pm 1.2}$ & $\underline{32.9 \pm 2.4}$ & $\underline{20.6 \pm 1.8}$ & $\underline{7.5 \pm 0.6}$ & \multirow{2}{*}{60.0} \\
\hline & $9.7 \pm 0.8$ & $12.9 \pm 2.6$ & $21.5 \pm 3.4$ & $16.7 \pm 1.9$ & $7.3 \pm 0.8$ & \\
\hline \multirow{2}{*}{$\mathrm{Cu}$} & $\underline{6.8 \pm 0.2}$ & $\underline{5.3 \pm 0.2}$ & $\underline{6.4 \pm 0.2}$ & $\underline{5.9 \pm 0.2}$ & $\underline{2.8 \pm 0.2}$ & \multirow{2}{*}{50.0} \\
\hline & $6.9 \pm 0.1$ & $6.7 \pm 0.3$ & $7.6 \pm 0.1$ & $7.2 \pm 0.2$ & $4.9 \pm 0.1$ & \\
\hline \multirow{2}{*}{$\mathrm{Ni}$} & $\underline{0.8 \pm 0.1}$ & $\underline{2.3 \pm 0.2}$ & $\underline{1.8 \pm 0.1}$ & $\underline{4.7 \pm 0.4}$ & $\underline{4.4 \pm 0.3}$ & \multirow{2}{*}{36} \\
\hline & $\overline{1.1 \pm 0.1}$ & $3.1 \pm 0.2$ & $2.1 \pm 0.1$ & $6.4 \pm 0.4$ & $\overline{5.9 \pm 0.6}$ & \\
\hline \multirow{2}{*}{$\mathrm{Cr}$} & $\underline{1.9 \pm 0.2}$ & $\underline{3.0 \pm 0.5}$ & $\underline{3.6 \pm 0.2}$ & $\underline{4.8 \pm 0.2}$ & $\underline{6.4 \pm 0.4}$ & \multirow{2}{*}{15.0} \\
\hline & $\overline{1.4 \pm 0.3}$ & $\overline{3.9 \pm 0.5}$ & $\overline{4.1 \pm 0.3}$ & $\overline{4.4 \pm 0.4}$ & $\overline{9.8 \pm 0.6}$ & \\
\hline \multirow{2}{*}{$\mathrm{Pb}$} & $\underline{0.9 \pm 0.2}$ & $\underline{3.2 \pm 0.4}$ & $\underline{2.9 \pm 0.3}$ & $\underline{4.2 \pm 0.4}$ & $\underline{5.2 \pm 0.5}$ & \multirow{2}{*}{60.0} \\
\hline & $1.1 \pm 0.1$ & $\overline{3.5 \pm 0.3}$ & $\overline{3.4 \pm 0.2}$ & $\overline{5.8 \pm 0.2}$ & $\overline{7.6 \pm 0.1}$ & \\
\hline \multirow{2}{*}{ Co } & $\underline{0.3 \pm 0.1}$ & $\underline{1.4 \pm 0.1}$ & $\underline{1.3 \pm 0.09}$ & $\underline{0.2 \pm 0.01}$ & $\underline{3.5 \pm 0.32}$ & \multirow{2}{*}{12.0} \\
\hline & $\overline{0.4 \pm 0.1}$ & $\overline{1.6 \pm 0.2}$ & $1.4 \pm 0.08$ & $0.2 \pm 0.01$ & $4.3 \pm 0.24$ & \\
\hline \multirow{2}{*}{$\mathrm{Cd}$} & $\underline{0.2 \pm 0.1}$ & $\underline{0.4 \pm 0.1}$ & $\underline{0.4 \pm 0.02}$ & $\underline{0.6 \pm 0.01}$ & $\underline{0.4 \pm 0.01}$ & \multirow{2}{*}{1.0} \\
\hline & $0.2 \pm 0.1$ & $0.5 \pm 0.1$ & $0.5 \pm 0.01$ & $0.6 \pm 0.01$ & $0.5 \pm 0.01$ & \\
\hline
\end{tabular}

Примечание: жирным шрифтом выделены концентрации элементов, для которых различия между фоновой и загрязненной территориями достоверны при $\mathrm{p}<0.05$. Прочерк означает отсутствие данных.

стороны, может быть связано с невысокой потребностью в них, а с другой - с существованием механизмов, регулирующих накопление и распределение химических элементов между различными органами (Битюцкий, 2011).

Загрязнение растений при техногенном воздействии происходит как за счет поверхностного осаждения, так и фолиарного и почвенного поглощения. Органогенные горизонты почвы являются основным источником питания кустарничковых растений, а также биогеохимическим барьером на пути нисходящей миграции химических элементов и аккумулятором загрязняющих веществ техногенного происхождения. Полученные нами данные показали, что почвы в насаждениях импактной зоны имеют более кислую реакцию среды $\left(\mathrm{pH}_{\mathrm{KCl}}=3.3 \pm 0.3\right)$, чем на фоновой территории $\left(\mathrm{pH}_{\mathrm{KCl}}=4.1 \pm 0.2\right)$. Среднее содержание подвижных форм $\mathrm{Zn}, \mathrm{Co}, \mathrm{Cd}$ существенно не изменялось, тогда как концентрации S и Ni превышали фоновый уровень в 1.3 раза, $\mathrm{Cr}, \mathrm{Pb}$ - в 1.5 раза, $\mathrm{Fe}, \mathrm{Cu}-$ в 1.8 раза, что может быть связано как с поступлением этих элементов в составе промышленных выбросов, так и с увеличением их подвижности при подкислении почвенного раствора выпадающими серосодержащими соединениями. При этом следует отметить, что содержание рассматриваемых элементов не превышали существующие предельно допустимые концентрации (ПДК). Снижение содержания подвижных форм в почвах импактной территории отмечено только для Мn. Выявленные 
изменения кислотности почв и содержания ряда химических элементов в ней могут служить причиной различий в концентрации элементов в органах черники в фоновых и техногенных условиях.

Анализ данных по содержанию химических элементов в растениях $V$. myrtillus, произрастающих на техногенно-загрязненной территории, показал, что в корнях концентрации $\mathrm{Fe}, \mathrm{Cr}, \mathrm{Co}, \mathrm{Cd}$ находились в пределах диапазона варьирования фоновых значений, для $\mathrm{S}, \mathrm{Cu}, \mathrm{Ni}$ и $\mathrm{Pb}$ отмечена слабая тенденция к увеличению содержания, для $\mathrm{Mn}$ и $\mathrm{Zn}$, напротив, выявлена тенденция к снижению. В целом полученные данные отражают барьерную функцию корневой системы на пути миграции загрязняющих веществ из почвы в растения. Известно, что благодаря наличию в корнях микоризы, снижающей поглощение избыточных количеств химических элементов из почвы и проявляющей тем самым протекторные свойства, растения рода Vaccinium могут существовать даже при высоком уровне почвенного загрязнения (Bradley et al., 1982).

В листьях и стеблях $V$. myrtillus на импактной территории обнаружено увеличение концентрации $\mathrm{S}$ в 1.7-1.8 раза и снижение содержания $\mathrm{Mn}$ и $\mathrm{Zn}$ в 1.5-2.3 раза по сравнению с фоновыми значениями. Подобная тенденция в условиях техногенного воздействия была ранее отмечена нами для хвои Pinus sylvestris L. на территории Западного Забайкалья (Афанасьева и др., 2010), а также рядом авторов для $V$. vitis-idaea L. и $V$. myrtillus (Steinnes et al., 2000; Артемкина, 2010). Снижение уровня $\mathrm{Mn}$ и $\mathrm{Zn}$ в растениях в условиях загрязнения может происходить вследствие вытеснения катионов этих металлов из почвенно-поглощающего комплекса ионами водорода, алюминия и тяжелых металлов или осаждения в виде малорастворимых сульфидов. Кроме того, уменьшение концентрации этих элементов может быть обусловлено проявлением антагонизма в парах: Fe-Mn, Ni-Mn, $\mathrm{Cu}-\mathrm{Mn}, \mathrm{Zn}-\mathrm{Ni}, \mathrm{Zn}-\mathrm{Cu}$, проявляющегося как на стадии поглощения их корнями из почвы, так и при транспорте внутри растения (KabataPendias, 2010).

В ягодах черники концентрации большей части анализируемых элементов находились в пределах фоновых значений, для Fe отмечена тенденция к увеличению содержания, тогда как уровень Mn был снижен в 2.1 раза по сравнению с фоновыми концентрациями, $\mathrm{Zn}$ - в 1.7 раза, $\mathrm{Cr}$ - в 1.4 раза. Возможно, снижение содержания микроэлементов обусловлено нарушением их транспортировки из вегетативных органов.

Для оценки миграции химических элементов в системе почва-растение были рассчитаны коэффициенты накопления, позволяющие оценить аккумулирующую способность растений. Установлена значительная вариабельность этих коэффициентов для надземных и подземных органов V. myrtillus (табл. 2). В фоновых условиях к энергично накапливаемым элементам относится $\mathrm{S}\left(100>K_{\mu}\right.$ $\geq 10)$, к элементам сильного накопления - Mn, $\mathrm{Zn}, \mathrm{Cu}, \mathrm{Cd}\left(10>K_{t} \geq 1\right)$. Низкая степень аккумуляции свойственна для $\mathrm{Fe}, \mathrm{Cr}, \mathrm{Pb}, \mathrm{Ni}, \mathrm{Co}$ (1> $\left.K_{H} \geq 0.1\right)$. На техногеннозагрязненной территории коэффициенты накопления большинства рассмотренных элементов снижаются, причем для биофильных элементов в 1.4-2.0 раза, что свидетельствует о нарушении процессов их аккумуляции корнями растений.

Чтобы оценить экологическую безопасность ягод V. myrtillus, данные по концентрации тяжелых металлов сравнивали со значениями ПДК нормируемых элементов, разработанных для чая и лекарственных растений: $\mathrm{Pb}(6$ мг/кг) и $\mathrm{Cd}(1$ мг/кг) (СанПиН 2.3.2.1078-01). Обнаружено, что содержание этих элементов в ягодах растений, произрас- 
Таблица 2. Коэффициенты накопления химических элементов в надземных и подземных органах V. myrtillus на фоновой (1) и техногенно-загрязненной (2) территориях Южного Прибайкалья

\begin{tabular}{|c|c|c|c|c|c|c|c|c|}
\hline \multirow{2}{*}{ Элемент } & \multicolumn{2}{|c|}{ Ягоды } & \multicolumn{2}{|c|}{ Листья } & \multicolumn{2}{|c|}{ Стебли } & \multicolumn{2}{|c|}{ Корни } \\
\hline & 1 & 2 & 1 & 2 & 1 & 2 & 1 & 2 \\
\hline $\mathrm{S}$ & 81 & 72 & 93 & 134 & 39 & 52 & 31 & 30 \\
\hline Mn & 2.0 & 1.1 & 6.9 & 3.6 & 7.7 & 4.7 & 1.8 & 1.7 \\
\hline $\mathrm{Fe}$ & 0.1 & 0.1 & 0.4 & 0.2 & 0.4 & 0.2 & 0.5 & 0.3 \\
\hline $\mathrm{Zn}$ & 2.2 & 1.3 & 2.6 & 1.8 & 4.4 & 2.9 & 2.7 & 2.3 \\
\hline $\mathrm{Cu}$ & 2.4 & 1.4 & 1.9 & 1.4 & 2.3 & 1.6 & 2.1 & 1.5 \\
\hline $\mathrm{Cr}$ & 0.3 & 0.1 & 0.5 & 0.4 & 0.6 & 0.4 & 0.8 & 0.4 \\
\hline $\mathrm{Pb}$ & 0.2 & 0.1 & 0.6 & 0.5 & 0.6 & 0.4 & 0.8 & 0.8 \\
\hline $\mathrm{Ni}$ & 0.2 & 0.2 & 0.5 & 0.5 & 0.4 & 0.4 & 1.0 & 1.1 \\
\hline $\mathrm{Co}$ & 0.1 & 0.1 & 0.4 & 0.4 & 0.4 & 0.3 & 0.1 & 0.1 \\
\hline $\mathrm{Cd}$ & 0.5 & 0.4 & 1.0 & 1.0 & 1.0 & 1.0 & 1.5 & 1.2 \\
\hline
\end{tabular}

Примечание: жирным шрифтом выделены значения коэффициентов, для которых различия между фоновой и загрязненной территориями достоверны при $\mathrm{p}<0.05$.

тающих в окрестностях комбината, значительно ниже их ПДК. Для остальных изученных элементов ПДК отсутствуют.

\section{Содержание фенольных соединений}

в растениях $V$. myrtillus

Многие неблагоприятные факторы среды инициируют окислительный стресс, при котором внутри клеток образуется большое количество активных форм кислорода с высокой окислительной способностью - свободных радикалов, представляющих угрозу для клеток и ингибирующих ростовую активность (Биохимические..., 1997; Чупахина и др., 2011). Оценить эти проявления можно по интенсивности работы антиоксидантной системы защиты растительных клеток, в которую входит большое число компонентов, участвующих в контроле уровня свободных радикалов, в том числе и фенольные соединения. Характерной их особенностью является легкая окисляемость, способность к взаимодействию с белками и комплексообразование с ионами металлов. Благодаря этим свойствам, а также значительному структурному разнообразию спектр функций фенольных соединений в жизни растений весьма широк (Запрометов, 1993).

Одной из наиболее крупных групп фенольных соединений и важной составной частью растительного организма являются флавоноиды. Они принимают активное участие в окислительно-восстановительных процессах, выступают необходимым компонентом дыхательной пероксидазной системы, влияют на проницаемость мембран, служат субстратами ряда ферментов, обеспечивают защиту клеток и метаболитов растения от окисления, повреждения бактериями и патогенными грибами, УФизлучения.

Значимое влияние на синтез фенольных соединений оказывают некоторые элементы минерального питания, в частности медь, азот, фосфор и др. Так, медь входит в состав ферментов, катализирующих окислительное расщепление фенолов (полифенолоксидаза), их превращение и образование (фенолоксидаза, 3-дегидрохинатсинтаза). Дефицит азота и фосфора стимулирует накопление фенольных 
соединений, а их избыток сопровождается интенсивным развитием надземной фитомассы и обеднением фенольными соединениями (Кунаева, 1986; Запрометов, 1993). В условиях техногенного загрязнения при нарушении питательного статуса растений (изменении концентрации биофильных и токсичных элементов в органах), как правило, содержание фенольных соединений увеличивается (Био- химические..., 1997; Pasqualini et al., 2003; Артемкина, 2010; Mroz, Demczuk, 2010).

Анализ полученных данных показал, что в фоновых условиях Южного Прибайкалья общее содержание фенольных соединений в растениях черники снижается в ряду листья > стебли > ягоды > корни (рис. 1). При этом уровень их накопления в листьях находится в пределах средней концентрации
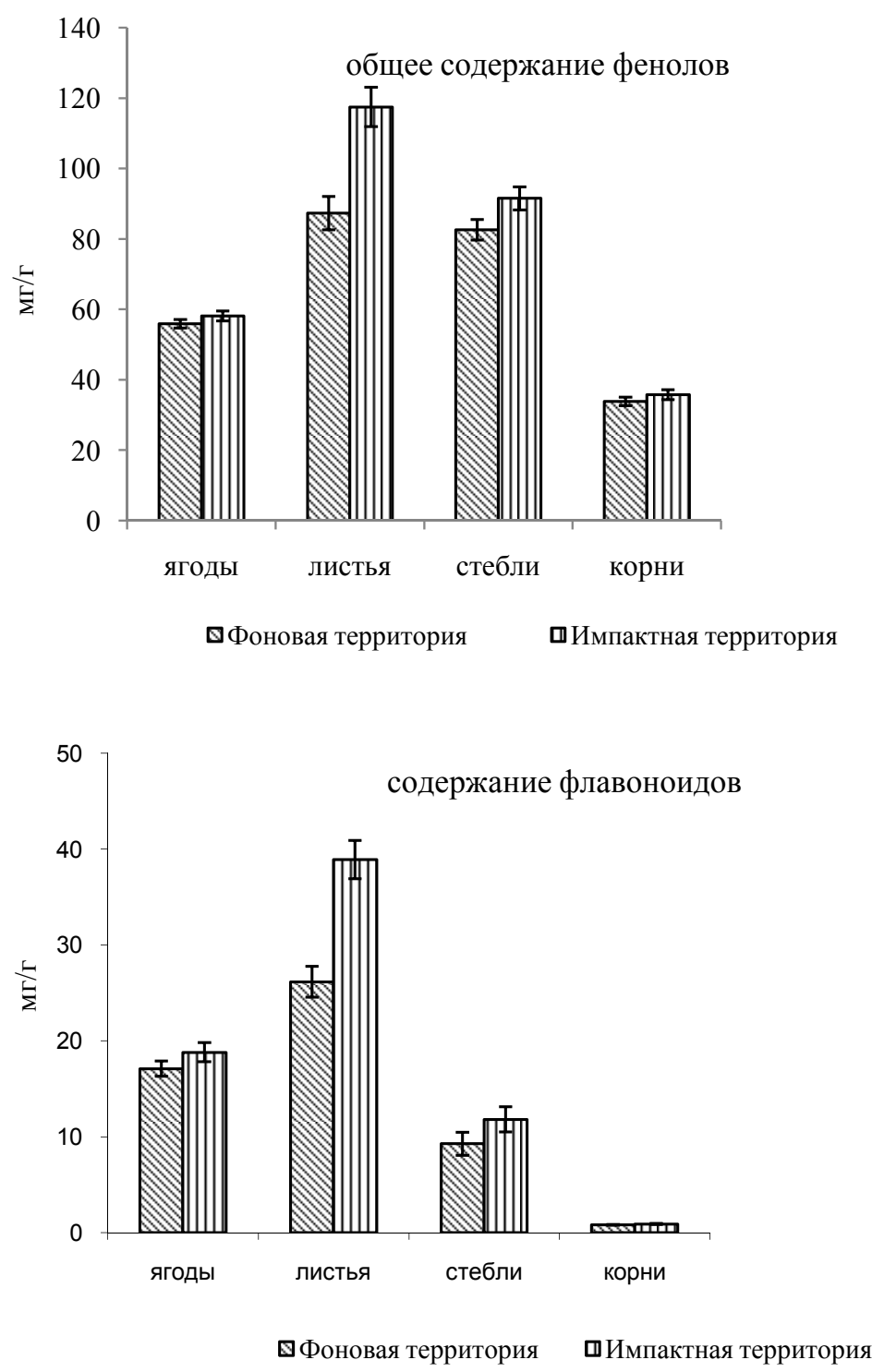

Рис. 1. Содержание фенольных соединений в растениях Vaccinium myrtillus на фоновой и техногеннозагрязненной территориях Южного Прибайкалья 
фенольных соединений (76.2 мг/г), установленной для $V$. myrtillus на территории Польши (Mroz, Demczuk, 2010). В окрестностях комбината достоверное увеличение концентрации общих фенолов отмечено только в листьях черники - их содержание превышало фоновое значение в 1.3 раза $(p=0.05)$. В ягодах, стеблях и корнях растений, произрастающих в импактной зоне, концентрация фенолов находилась в пределах диапазона варьирования, установленного для фоновой территории.

На фоновой территории наиболее высокие концентрации флавоноидов отмечены в листьях черники - в среднем 26 мг/Г сухого вещества, или $30 \%$ от общего содержания фенольных соединений (ОСФ). В ягодах их концентрация несколько ниже - 17.1 мг/г, или $31 \%$ ОСФ. В стеблях содержание флавоноидов снижалось почти в три раза - 9.3 мг/г, или $11 \%$ ОСФ, в корнях обнаружены лишь следы этих соединений -0.8 мг/г, или $2 \%$ ОСФ.

Сравнительный анализ данных по сумме флавоноидов показал, что на импактной территории их содержание в листьях увеличивалось в 1.5 раза $(p=0.05)$, в побегах - в 1.3 раза ( $p=0.05)$ по сравнению с фоновыми значениями, что может свидетельствовать об изменении хода метаболических процессов и фитохимического состава растений, произрастающих в загрязненной промышленными выбросами среде. Кроме того, отмеченный рост содержания флавоноидов в листьях по сравнению с фоном может быть связан с некоторым изреживанием древесного полога и, как следствие, усилением действия УФ-излучения (Johanson, 1995). На основе корреляционного анализа данных отмечена тесная корреляционная зависимость между ОСФ и концентрацией флавоноидов в надземных и подземных органах $V$. myrtillus $(r=0.71, p=0.05)$.
Результаты корреляционного анализа данных элементного состава листьев черники и содержания в них вторичных метаболитов свидетельствуют о том, что при антропогеном стрессе, т.е. увеличении содержания в листьях $V$. myrtillus серы $(r=0.68-0.74, p=0.05)$ и снижении концентрации марганца и цинка $(r=-0.56-0.62, p=0.05)$, уровень содержания фенолов и флавоноидов в фотосинтезирующих органах возрастает. Для стеблей, корней и ягод эта зависимость значительно слабее или вообще отсутствует.

\section{Морфометрические параметры} и урожайность V. myrtillus

Исследование морфометрических параметров растений признано одной из важных задач при оценке состояния ценопопуляций, поскольку их детальный анализ позволяет выявить механизмы устойчивости популяции к воздействию разнообразных экологических и антропогенных факторов. На основе морфометрических параметров, внешне отражающих интенсивность ростовых и продукционных процессов, эффективность использования ресурсов местопроизрастания, устойчивость к различным стрессовым воздействиям можно определить жизненное состояние растений (Злобин, 1989).

Сравнительный анализ морфометрических параметров растений $V$. myrtillus (средних значений и частотных распределений) показал, что на импактной территории происходит достоверное уменьшение средней высоты парциальных кустов и протяженности кроны в 1.4 раза по сравнению с фоновыми значениями $(p=0.05)$, тогда как диаметр кроны практически не изменялся (табл. 3). Кроме того, в условиях техногенного воздействия отмечалось сокращение интервала варьирования этих параметров и увеличение доли кустов нижних классов морфометрических 
Таблица 3. Морфометрические параметры растений $V$. myrtillus $(M \pm m)$ и урожайность ягод на фоновой и техногенно-загрязненной территориях Южного Прибайкалья, n=10 для каждой территории

\begin{tabular}{|c|c|c|}
\hline Показатель & Фоновая территория & $\begin{array}{c}\text { Техногенно-загрязненная } \\
\text { территория }\end{array}$ \\
\hline Высота парциального куста, см & $29.3 \pm 0.9$ & $21.2 \pm 0.6$ \\
\hline Протяженность кроны, см & $17.6 \pm 0.8$ & $12.8 \pm 1.9$ \\
\hline Диаметр кроны, см & $12.3 \pm 2.6$ & $10.8 \pm 1.9$ \\
\hline Запас надземной фитомассы, г/м² & $72.4 \pm 8.7$ & $48.7 \pm 8.1$ \\
\hline Количество ягод на одном кусте, шт. & $9.1 \pm 1.5$ & $6.1 \pm 0.8$ \\
\hline Масса ягод на одном кусте, г & $2.0 \pm 0.5$ & $\mathbf{1 . 1} \pm \mathbf{0 . 3}$ \\
\hline Масcа 1 ягоды, г & $0.22 \pm 0.01$ & $0.18 \pm 0.02$ \\
\hline Количество ягод, шт/м² & $107.6 \pm 18.1$ & $78.1 \pm 4.8$ \\
\hline Урожайность ягод, г/м² & $23.7 \pm 3.6$ & $14.1 \pm 2.7$ \\
\hline
\end{tabular}

Примечание: жирным шрифтом выделены значения показателей, для которых различия между фоновой и загрязненной территориями достоверны при $\mathrm{p}<0.05$.

показателей, что особенно характерно для высоты парциальных кустов (рис. 2). Снижение морфометрических параметров парциальных кустов приводит к уменьшению их надземной фитомассы почти в 1.5 раза $(p=0.05)$ по сравнению с фоновой территорией.

Изучение плодоношения V. myrtillus показало, что в фоновых условиях Южного Прибайкалья количество ягод на одном парциальном кусте варьирует от 0 до 17 шт. при среднем значении 9.1 шт. (коэффициент вариации равен 57 \%). При расчете урожайности ягод в год наблюдения отмечено, что эта величина колеблется в широких пределах от 11 до 34 г/ $\mathrm{M}^{2}$ - и соответствует среднемноголетним данным, приводимым в литературе для естественных природных популяций этого вида в разных типах леса Байкальского биосферного заповедника, расположенного в 50 км от комбината (Субботина, 1988). Обнаружено, что в фоновых условиях урожайность ягод на пробных площадях в большей степени зависит от количества ягод на одном парциальном кусте и их массы $(r=0.55-0.68$, $p<0,05)$ и в меньшей степени от количества плодоносящих кустов $(r=0.34-0.45, p<0,05)$.
Высота куста, параметры кроны существенного влияния на величину урожайности ягод не оказывают.

На техногенно-загрязненной территории интервал варьирования числа плодов составил 0-11 шт/куст при среднем значении 6.1 шт. (коэффициент вариации $43 \%$ ), что в 1.5 раза ниже, чем на фоновой территории. Отмечается не только уменьшение количества ягод, но также их массы на одном парциальном кусте и средней урожайности в 1.7-1.8 раза ( $p=0.05)$, тогда как средняя масса одной ягоды в фоновых сообществах и на импактной территории статистически не различалась. Учитывая, что урожайность ягод черники во многом зависит от погодных условий (количества осадков, температуры, весенних заморозков) (Субботина, 1988), нельзя утверждать, что наблюдаемые изменения связаны только с выбросами ОАО «БЦБК». В то же время результаты проведенных исследований показали, что при воздействии эмиссий ухудшается питательный режим почв и питательный статус растений, произрастающих в окрестностях комбината, что может служить одной из причин изменения морфометрических параметров 

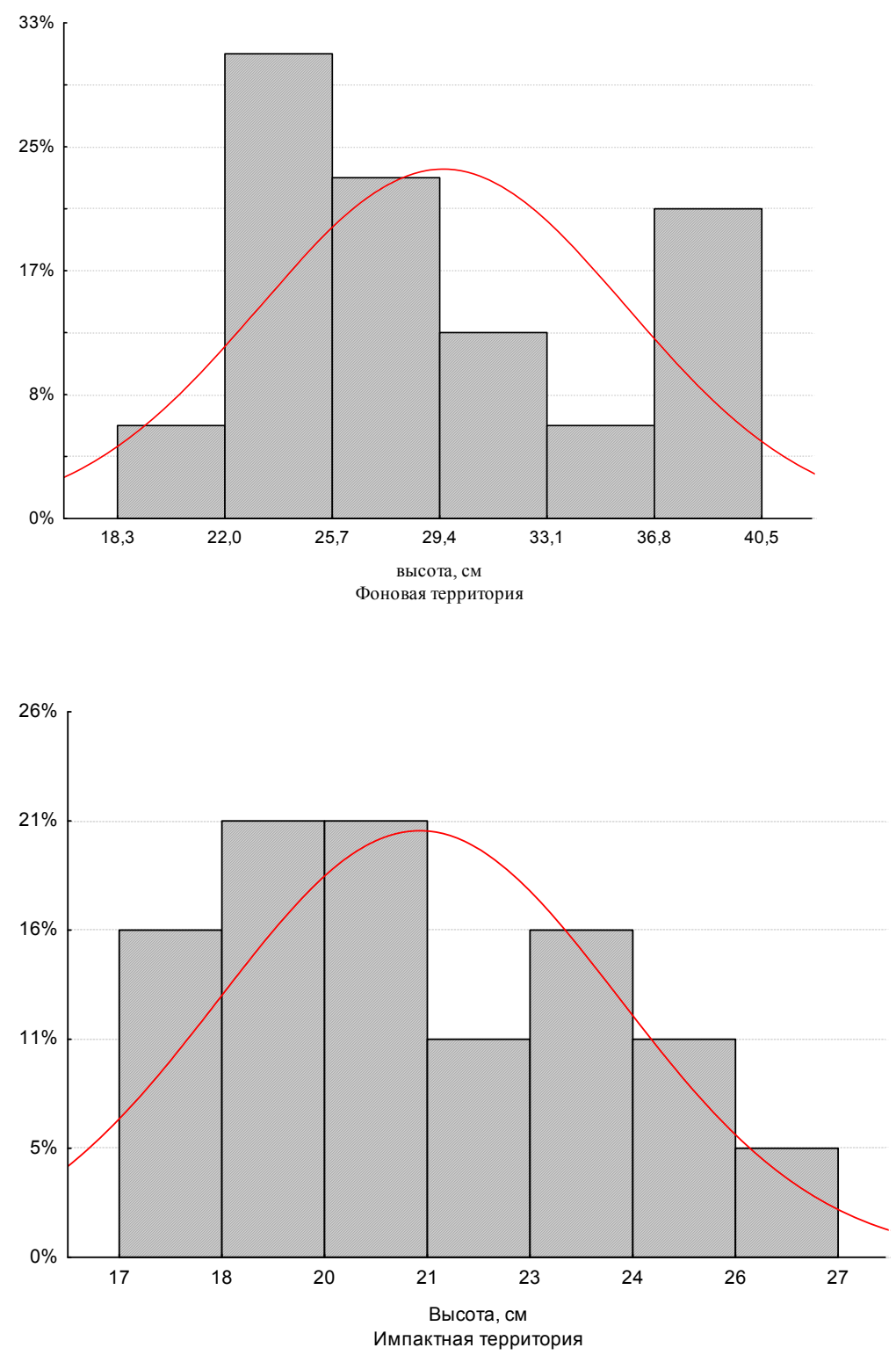

Рис. 2. Частотное распределение высоты парциальных кустов Vaccinium myrtillus на фоновой и техногеннозагрязненной территориях Южного Прибайкалья

кустов, а следовательно, и состояния всей популяции в целом.

\section{Заключение}

В ходе проведенных исследований определены концентрации и характер распределения по органам растений $V$. myrtillus химических элементов (S, Mn, Fe, $\mathrm{Zn}, \mathrm{Cu}, \mathrm{Co}, \mathrm{Cr}, \mathrm{Ni}$,
$\mathrm{Pb}, \mathrm{Cd})$ на фоновой и техногенно-загрязненной территориях Южного Прибайкалья. В фоновых условиях корни черники отличаются наиболее высоким содержанием $\mathrm{Fe}, \mathrm{Ni}, \mathrm{Cr}, \mathrm{Pb}, \mathrm{Cd}$, стебли - Mn, Zn, листья - S и Сo, ягоды - Cu.

В условиях атмосферного промышленного загрязнения в вегетативных органах V. myrtillus содержание серы возрастало в 
1.7-1.8 раза, тогда как концентрации марганца и цинка, напротив, снижались в 1.5-2.3 раза.

В ягодах при незначительном накоплении серы (в 1.2 раза выше фоновых значений) отмечалось снижение содержания хрома, цинка и марганца в 1.4-2.1 раза, что снижает питательную и фармакологическую ценность ягод, хотя они остаются экологически безопасны для здоровья человека.

Установлено, что наиболее высокие концентрации фенольных соединений характерны для листьев черники. В условиях техногенного загрязнения содержание флавоноидов в ассимиляционных органах черники увеличивается и может служить индикатором стрессового состояния растений.
На загрязненной аэропромвыбросами ОАО «БЦБК» территории отмечалось уменьшение высоты парциальных кустов, протяженности кроны, количества и массы ягод на кусте, а также запаса надземной фитомассы и урожайности ягод в 1.4-1.8 раза, что свидетельствует о неблагоприятных условиях существования растений. Таким образом, на основании полученных данных можно заключить, что, несмотря на сокращение объемов атмосферных выбросов загрязняющих веществ, ОАО «БЦБК» в период проведенных исследований продолжал оказывать значимое влияние на состояние кустарничковых растений, в частности $V$. myrtillus, произрастающих в его окрестностях.

\section{Список литературы}

1. Артемкина Н.А. (2010) Содержание фенольных соединений и элементный состав Vaccinium vitis-idaea (Ericaceae) в еловых лесах Кольского полуострова в условиях техногенного загрязнения. Раст. ресурсы 46 (2): 86-97.

2. Афанасьева Л.В., Михайлова Т.А., Кашин В.К. (2010) Состояние сосновых древостоев в условиях техногенного загрязнения в Республике Бурятия. Раст. ресурсы 46 (2): 51-61.

3. Байкал. Атлас. (1993) Ред. Г.И. Галазия. М.: Федеральная служба геодезии и картографии России, 160 с.

4. Безель В.С., Позолотина В.Н., Бельский Е.А., Жуйкова Т.В. (2001) Изменчивость популяционных параметров: адаптация к токсическим факторам среды. Экология 6: 447-453.

5. Битюцкий Н.П. (2011) Микроэлементы высших растений. СПб.: Изд-во СПб ун-та, 368 с.

6. Государственный доклад «О состоянии и об охране окружающей среды в Иркутской области в 2011 г.» (2012) Иркутск: Изд-во ООО «Форвард», 388 с.

7. Дикорастущие полезные растения России (2001) Ред. А.Л. Буданцева. СПб.: СПХФА, 663 с.

8. Зайцев Г.Н. (1990) Математика в экспериментальной ботанике. М.: Наука, 296 с.

9. Запрометов М.Н. (1993) Фенольные соединения. М.: Наука, 272 с.

10. Злобин Ю.А. (1989) Принципы и методы изучения ценотических популяций растений: учебно-методическое пособие. Казань: Изд-во Казан. ун-та, 147 с.

11. Ильин В.Б. (1995) Система показателей для оценки загрязненности почв тяжелыми металлами. Агрохимия 1: 94-99.

12. Кунаева Р.М. (1986) Гидролитические и окислительные ферменты обмена фенольных соединений. Алма-Ата: Наука, 157 с.

13. Лукина Н.В., Никонов В.В. (1996) Биогеохимические циклы в лесах Севера в условиях аэротехногенного загрязнения. В 2-х ч. Апатиты: Изд-во Кольского научного центра РАН, Ч. 1. 213c; Ч. 2., 192 c.

$$
-345-
$$


14. Мазная Е.А., Лянгузова И.В. (2010) Эколого-популяционный мониторинг ягодных кустарничков при аэротехногенном загрязнении. СПб.: ВВМ, 195 с.

15. Методы биохимического исследования растений (1987). Ред. А.И. Ермакова. Л.: Агропромиздат, Ленингр. отд-е, 430 с.

16. Методы изучения лесных сообществ (2002) Ред. В.Т. Ярмишко. СПб.: НИИ Химии СПбГУ, $240 \mathrm{c}$.

17. Мочалова А.Д. (1975) Спектрометрический метод определения серы в растениях. Сельское хозяйство за рубежом 4: 17.

18. Проблемы экологии растительных сообществ Севера (2005) Ред. В.Т. Ярмишко. СПб.: BBM, $450 \mathrm{c}$.

19. Субботина Л.В. (1988) Некоторые данные по динамике урожайности черники. В: Растительность хребта Хамар-Дабан. Новосибиркск: Наука, С.79-91.

20. Судачкова Н.Е., Шеин И.В., Романова Л.И., Милютина Л.И. (1997) Биохимические индикаторы стрессового состояния древесных растений. Новосибирск: Наука, 176 с.

21. Теория и практика химического анализа почв (2006) Ред. Л.А. Воробьевой. М.: ГЕОС, $400 \mathrm{c}$.

22. Типы лесов гор Южной Сибири (1980). Ред. В.Н. Смагина. Новосибирск: Наука, 366 с.

23. Чупахина Г.Н., Масленников П.В., Скрыпник Л.Н. (2011) Природные антиоксиданты (экологический аспект). Калининград: Изд-во БФУ им. И. Канта, 111 с.

24. Чулджиян Х., Кирвета С., Фацек 3. (1988) Тяжелые металлы в почвах и растениях. Экологическая конференция. Вып.1. Братислава, с. 5-24.

25. Bialońska D., Sawicka-Kapusta K., Kuraś M., Tykarska T., Zobel A.M. (2007) Phenolic compounds and cell structure in bilberry leaves affected by emissions from a $\mathrm{Zn}-\mathrm{Pb}$ smelter. Water, Air and Soil Pollution 181 (1-4): 123-133.

26. Bradley R., Burt A.J., Read D.J. (1982) The biology of mycorrhiza in the Ericaceae: VIII. The role of mycorrhizal infection in heavy metal resistance. New Phytol. 91: 197-209.

27. Johanson U., Gehrke C., Bjorn L.O., Callaghan T.V. (1995) The effects of enhanced UV-B radiation on the growth of dwarf shrubs in a Subarctic heathland. Functional Ecology 9 (6): 713-719.

28. Kabata-Pendias A. (2010) Trace elements in soils and plants. 4th Edition. Boca Raton, FL: Crc Press, $548 \mathrm{p}$.

29. Marschner H. (1995) Mineral nutrition of higher plants. London: Academic Press, 889 p.

30. Michalak A. (2006) Phenolic compounds and their antioxidant activity in plants growing under heavy metal stress. Polish J. of Environ. Stud. 15: 523-530.

31. Mroz L., Demczuk M. (2010) Contents of phenolics and chemical elements in bilberry (Vaccinium myrtillus L.) leaves from copper smelter area (SW Poland). Polish Journal of Ecology 58(3): 475-486.

32. Pasqualini V., Robles C., Garzino S., Greff S., Bousquet-Melou A., Bonin G. (2003) Phenolic compounds content in Pinus halepensis Mill. needles: a bioindicator of air pollution. Chemosphere 52: $239-248$

33. Steinnes E., Lukina N., Nikonov V., Aamlid D., Royset O. (2000) A gradient study of 34 elements in the vicinity of a copper-nikel in the Kola Peninsula. Environ. Monit. and Assess. 60 (1): $71-88$. 